\title{
PERANAN KONSELOR DALAM MENANGANI ANAK BERKEBUTUHAN KHUSUS
}

\author{
Dulhadi
}

\begin{abstract}
Abstrak
Disadari bahwa tidak semua anak yang lahir ke dunia ini berada dalam kondisi sebagaimana yang diharapkan. Sebagian dari mereka ada yang lahir tidak normal.

Sekalipun lahir dalam keadaan normal, namun dalam pertumbuhan dan perkembangannya ada di antara mereka yang mengalami hambatan, gangguan, dan kelambatan. Bagi anak yang mengalami hal-hal seperti ini tentu perkembangannya tidak akan optimal. Oleh karena itu, anak yang seperti ini memerlukan penanganan dan perlakukan khusus. Anak-anak seperti inilah yang kemudian dikenal sebagai Anak Berkebutuhan Khusus. Sebagai manusia juga, anak berkebutuhan khusus harus ditangani secara intens dan serius. Konselor sebagai pihak yang mengenal dan memahami mereka diharapkan dapat berperan aktif dalam memberikan layanan kuratifnya.
\end{abstract}

Kata kunci: konselor, perlakuan, anak berkebutuhan khusus.

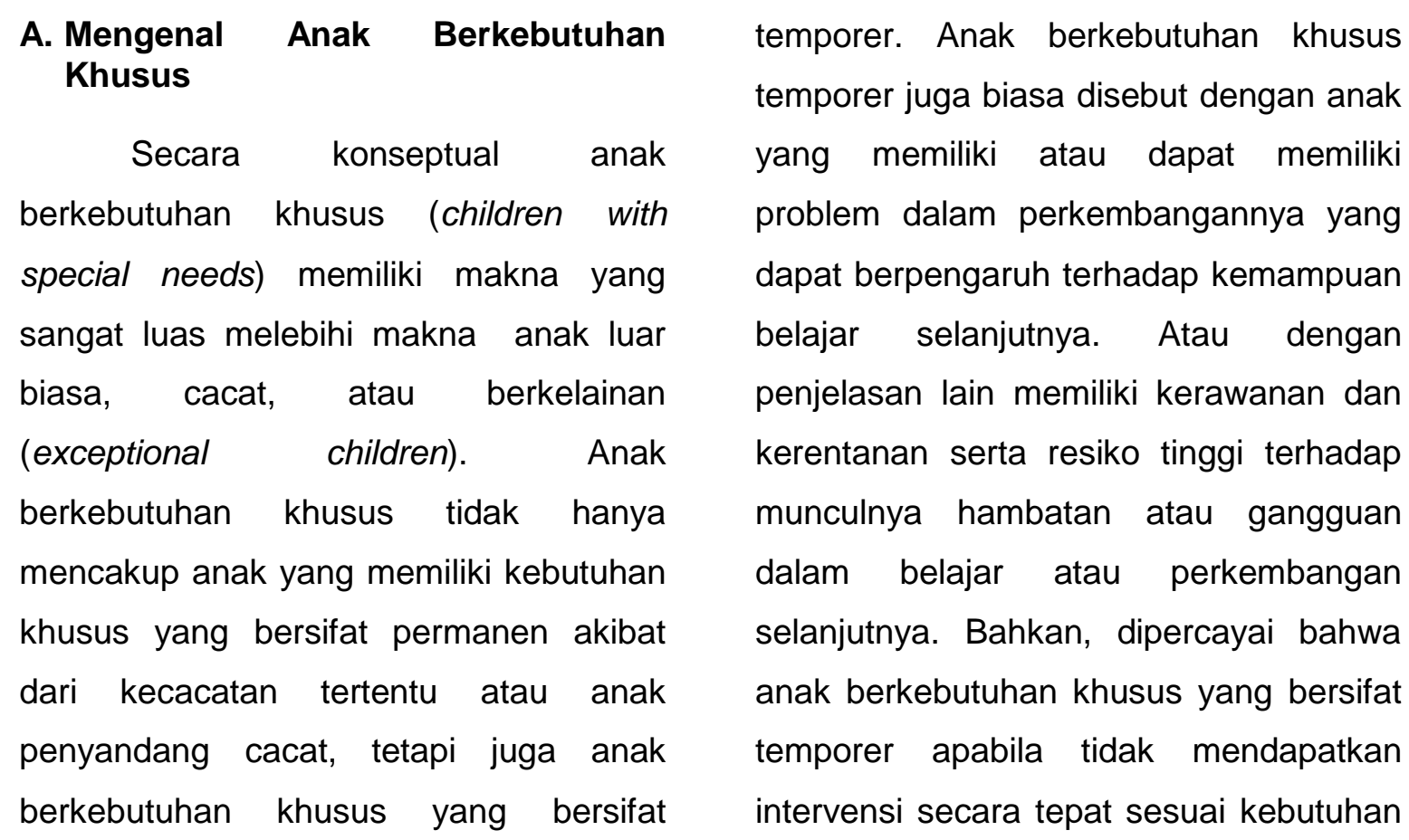


khususnya dapat berkembang menjadi permanen.

Salah satu cita-cita nasional yang harus terus diperjuangkan oleh bangsa Indonesia ialah upaya mencerdaskan kehidupan bangsa melalui pendidikan nasional. Masa depan dan keunggulan bangsa ditentukan oleh keunggulan Sumber Daya Manusia (SDM) yang dimiliki, disamping sumber daya lainnya. Sumber Daya Manusia yang berkualitas tinggi dapat menjadi subjek pembangunan untuk mengelola sumber daya lainnya bagi kepentingan kesejahteraan masyarakat.

Anak-anak dan generasi muda adalah tulang punggung negara dan merupakan kekayaan penting suatu negara dimana anak berkebutuhan khusus (ABK) merupakan bagian yang tidak terpisahkan dari kemajuan suatu bangsa. Anak kebutuhan khusus adalah anak dengan karakteristik khusus yang berbeda dengan anak pada umumnya tanpa selalu menunjukkan pada ketidakmampuan mental, emosi atau fisik. Yang termasuk kedalam anak berkebutuhan khusus antara lain: tunanetra, tunarungu, tunagrahita, tunadaksa, tunalaras, kesulitan belajar, gangguan perilaku dan kesehatan. Istilah lain bagi anak berkebutuhan khusus adalah anak luar biasa dan anak cacat.
Anak dengan kebutuhan khusus memiliki sikap dan perilaku yang berbeda dengan anak yang memiliki fisik dan mental yang normal. Untuk menyikapi hal tersebut maka diperlukan seorang konselor. Konselor adalah seorang yang mempunyai keahlian dalam melakukan konseling. Konselor memiliki peranan yang sangat penting dalam membina dan mengarahkan sikap dan perilaku anak berkebutuhan khusus.

Sampai saat ini pelayanan yang diberikan kepada anak berkebutuhan khusus masih sangat terbatas, baik oleh dokter, psikolog, maupun konselor dan layanan lainnya. Pelayanan bagi anak berkebutuhan khusus untuk saat ini masih terbatas di kota-kota besar dan jumlahnya juga terbatas.

Anak berkebutuhan khusus adalah anak dengan karakteristik khusus yang berbeda dengan anak pada umumnya tanpa selalu menunjukkan pada ketidakmampuan mental, emosi atau fisik. Istilah lain bagi anak berkebutuhan khusus adalah anak luar biasa dan anak cacat. Dalam buku yang berjudul Lexikana Universal Encyclopedia dijelaskan bahwa Pengertian Anak Luar Biasa atau istilah ketunaan digunakan untuk menunjukkan adanya kerusakan fisik atau kelemahan mental yang sekarang lebih sering digunakan untuk menjelaskan adanya kelemahan, 
gangguan atau hambatan dalam segi mental, fisik atau emosi yang begitu berat sehingga mengakibatkan keterbatasan bagi mereka dalam melakukan aktivitas. Yang termasuk kedalam anak berkebutuhan khusus antara lain:

\section{Tunanetra}

Tunanetra adalah istilah umum yang digunakan untuk kondisi seseorang yang mengalami gangguan atau hambatan dalam indra penglihatannya. Berdasarkan tingkat gangguannya/ kecacatannya tunanetra dibagi dua yaitu buta total (total blind) dan yang masih mempunyai sisa penglihatan (low visioan). Alat bantu untuk mobilitasnya bagi tuna netra dengan menggunakan tongkat khusus, yaitu berwarna putih dengan ada garis merah horizontal. Akibat hilang/berkurangnya fungsi indra penglihatannya maka tunanetra berusaha memaksimalkan fungsi indra-indra yang lainnya seperti, perabaan, penciuman, pendengaran, dan lain sebaginya sehingga tidak sedikit penyandang tuna netra yang memiliki kemampuan luar biasa misalnya di bidang musik atau ilmu pengetahuan. Huruf Braille adalah huruf timbul yang khusus digunakan untuk para penyandang tunanetra. Huruf ini terdiri dari kumpulan titik-titik yang disusun sedemikian rupa untuk menggantikan huruf biasa. Penulisannya pun menggunakan mesin ketik khusus Braile. Namun untuk penghitungan, penyandang tunanetra dapat menggunakan sempoa.

\section{Tunarungu}

Tunarungu adalah individu yang memiliki hambatan dalam pendengaran baik permanen maupun tidak permanen. Karena memiliki hambatan dalam pendengaran individu tunarungu memiliki hambatan dalam berbicara sehingga mereka biasa disebut tunawicara. Cara berkomunikasi dengan orang lain biasanya dilakukan dengan menggunakan bahasa isyarat. Untuk abjad jari telah dipatenkan secara internasional sedangkan untuk isyarat bahasa berbeda-beda di setiap negara. saat ini dibeberapa sekolah sedang dikembangkan komunikasi total yaitu cara berkomunikasi dengan melibatkan bahasa verbal, bahasa isyarat, dan bahasa tubuh. Individu tunarungu cenderung kesulitan dalam memahami konsep dari sesuatu yang abstrak. 


\section{Tunagrahita}

Tunagrahita adalah individu yang menunjukkan hambatan dalam perilaku adaptif. Penyandang tunagrahita memiliki kemampuan intelektual yang lamban dan ber-IQ di bawah 70 . Pembelajaran bagi individu tunagrahita lebih dititikberatkan pada kemampuan bina diri dan sosialisasi.

\section{Tunadaksa}

Tunadaksa adalah individu yang memiliki gangguan gerak yang disebabkan oleh kelainan neuromuskular dan struktur tulang yang bersifat bawaan, sakit atau akibat kecelakaan, termasuk celebral palsy, amputasi, polio, dan lumpuh. Tingkat gangguan pada tunadaksa ada tiga yaitu: ringan, yaitu memiliki keterbatasan dalam melakukan aktivitas fisik namun tetap masih dapat ditingkatkan melalui terapi. Sedang, yaitu memilki keterbatasan motorik dan mengalami gangguan koordinasi sensorik. Berat, yaitu memiliki keterbatasan total dalam gerakan fisik dan tidak mampu mengontrol gerakan fisik.

\section{Tunalaras}

Tunalaras adalah individu yang mengalami hambatan dalam mengendalikan emosi dan kontrol sosial. individu tunalaras biasanya menunjukan perilaku menyimpang yang tidak sesuai dengan norma dan aturan yang berlaku disekitarnya. Tunalaras dapat disebabkan karena faktor internal dan faktor eksternal yaitu pengaruh dari lingkungan sekitar.

\section{Kesulitan Belajar, gangguan perilaku, anak berbakat, dan anak dengan gangguan kesehatan}

Kesulitan Belajar, gangguan perilaku, anak berbakat, dan anak dengan gangguan kesehatan adalah individu yang memiliki gangguan pada satu atau lebih kemampuan dasar psikologis yang mencakup pemahaman dan penggunaan bahasa, berbicara dan menulis yang dapat mempengaruhi kemampuan berfikir, membaca, berhitung, berbicara yang disebabkan karena gangguan persepsi, brain injury, disfungsi minimal otak, dislexia, dan afasia perkembangan. individu kesulitan belajar memiliki IQ rata-rata atau diatas rata-rata, mengalami gangguan motorik persepsi-motorik, gangguan koordinasi gerak, gangguan orientasi arah dan ruang dan keterlambatan perkembangan konsep. 
Anak berkebutuan khusus biasanya bersekolah di Sekolah Luar Biasa (SLB) sesuai dengan kekhususannya masing-masing. SLB bagian A untuk tunanetra, SLB bagian $B$ untuk tunarungu, SLB bagian $C$ untuk tunagrahita, SLB bagian $D$ untuk tunadaksa, SLB bagian E untuk tunalaras dan SLB bagian G untuk cacat ganda.

\section{B. Permasalahan Anak Berkebutuhan Khusus}

Anak Berkebutuhan Khusus bisa memiliki masalah dalam sensorisnya, motoriknya, belajarnya, dan tingkahlakunya. Semua ini mengakibatkan terganggunya perkembangan fisik anak. Hal ini karena sebagian besar anak berkebutuhan khusus mengalami hambatan dalam merespon rangsangan yang diberikan lingkungan untuk melakukan gerak, meniru gerak dan bahkan ada yang memang fisiknya terganggu sehingga ia tidak dapat melakukan gerakan yang terarah dengan benar. Anak berkebutuhan khusus kerap kali kurang tangkas dan keseimbangan dalam perihal Gerak Motorik Kasar (Gross), sedangkan dalam Gerak Motorik Halus (Fine) AnakAnak Berkebutuhan Khusus kerap kurang terampil dan terkordinir dalam melaksanakan salah satu tugas. Dalam
Gerakan Sensorik, Anak-Anak Berkebutuhan Khusus cenderung Hiporeaktif (cuek) dan Hiperaktif (enggan belajar), fokus hanya pada detail tertentu/sempit/tak menyeluruh, dan mempunyai perhatian yang obsesif. Anak berkebutuhan khusus juga mempunyai minat terbatas, tak patuh, monoton, tantrum, mengganggu, agresif, impulsif, stimulasi diri, takut-cemas, kerap menangis.

Ketika belajar, anak berkebutuhan khusus sering melakukan kesalahan sensory memory karena memori mereka hanya pendek sekali jaraknya, mudah lupa, fakta tersimpan tetapi tidak dalam 1 kerangka konteks yang terjadi. Anak berkebutuhan khusus sebenarnya bisa memberi respon terhadap sesuatu dalam pembelajaran, tetapi mereka sulit menghadapi situasi baru. Sulit meniru aksi orang lain, namun bisa meniru katakata tetapi tidak memahami.

Anak berkebutuhan khusus mempunyai keterbatasan kemampuan komunikasi, gangguan bahasa verbalnonverbal, kesulitan menyampaikan keinginan, dan penggunaan bahasa repetitif (pengulangan). anak-anak berkebutuhan khusus mempunyai kelemahan dalam sequencing seperti kesulitan dalam mengurutkan aktivitas, bisa mengurutkan tetapi sulit mengembangkan sehingga kurang kreatif. 
Jika urutan aktivitas dirubah maka mereka bisa mengalami stress.

Gangguan Executive Function juga terdapat pada anak-anak berkebutuhan khusus seperti kesulitan mempertahankan atensi, mudah terdistraksi, tidak bisa menyelesaikan tugas, dan kurang kontrol diri serta sulit bergaul.

\section{Mengatasi Permasalahan Pada Anak Berkebutuhan Khusus}

Konselor sebagai seorang yang mempunyai keahlian dalam melakukan konseling sangat dibutuhkan untuk membantu anak berkebutuhan khusus dalam menyelesaikan permasalahan yang mereka hadapi. Permasalahan yang dihadapi untuk tiap anak berkebutuhan khusus berbeda-beda dikarenakan gangguan yang mereka hadapi bermacam-macam sesuai dengan kekurangan yang mereka miliki. Dengan demikian seorang konselor harus dapat memahami dengan baik setiap permasalahan yang dihadapi anak berkebutuhan khusus, sehingga solusi yang akan diberikan tepat sasaran.

Menangani anak-anak yang mengalami gangguan perkembangan (special need) seperti autism, hyperactivity, mental retarded, Rett syndrome, learning disorder, dan lainnya membutuhkan suatu keterampilan tersendiri, karena sebagian besar anakanak ini mengalami berbagai macam masalah dalam hal kemampuan berkomunikasi, perilaku, bahkan kemampuan sosialisasi dengan lingkungannya. Untuk itu diperlukan suatu rangkaian pelatihan yang pada akhirnya nanti mampu membantu anak-anak ini keluar dari masalahnya atau setidaknya mereka dapat mandiri dan dapat mengoptimalkan kemampuan yang mereka miliki saat ini serta bisa mengeksplorasi potensi dan bakatnya.

Terapi Okupasi merupakan salah satu cara untuk penyembuhan anak berkebutuhan khusus. Terapi okupasi mengandung makna bahwa dalam melakukan penyembuhan/ pengobatan menggunakan aktifitas atau pekerjaan sebagai medianya perlu merujuk pada kondisi gangguan fisik dan mental yang dialami anak berkebutuhan khusus.

Terapi okupasi mempunyai peranan sebagai sarana pencegahan, penyembuhan, penyesuaian diri, pengembangan kepribadian, pembawaan, kreatifitas, serta sebagai bekal hidup di masyarakat. Adapun jenis terapi okupasi yang diberikan terhadap anak berkebuthan khusu berbeda-beda, antara lain: 


\section{Terapi Okupasi untuk anak gangguan intelektual}

Problem dan penyelesaian yang dialami oleh anak dengan gangguan intelektual yaitu:

\section{a. Sensori Motorik}

Kegiatan yang diberikan untuk membantu mengembangkan sensori motorik antara lain: berlari mengikuti garis lurus, berlari dengan satu kaki, melempar benda kearah keranjang, meniru gambar, menyusun puzzle, mendengarkan musik, membedakan warna, meraba benda keras dan lunak, mencium bau-bauan, membedakan rasa, dan orientasi ruangan.

b. Fisik

Kegiatan yang diberikan untuk membantu mengarahkan gerakan fisik antara lain: naik sepeda statis, naik turun tangga, dan menarik pulley.

c. Kognitif

Kegiatan yang diberikan untuk membantu mengarahkan tingkah laku anak berkebutuhan khusus antara lain : bermain halma, dan senam diiringi musik.

d. Intra Personal - Interpersonal

Kegiatan yang diberikan dalam membantu mengarahkan intrapersonal dan interpersonal antara lain: berbelanja dan bermain layang-layang. e. Perawatan Diri

Kegiatan yang diberikan dalam membantu mengarahkan anak untuk mandiri antara lain: menggosok gigi, minum menggunakan gelas, menyisir rambut, memakai celana, memakai baju, latihan makan menggunakan sendok, merias diri, latihan mandi, mamakai sepatu, dan lain-lain.

f. Produktifitas

Kegiatan yang diberikan dalam meningkatkan produktifitas anak berkebutuhan khusus yaitu : berkebun, beternak, dan kerajinan.

\section{Terapi Okupsi Untuk Anak Gangguan Fisik}

Problem dan penyelesaian yang dialami oleh anak dengan gangguan intelektual yaitu:

a. Motorik

Kegiatan yang diberikan untuk membantu meningkatkan motorik pada anak dengan gangguan fisik yaitu : berjalan di atas balok titian, menarik beban, membuat sulak, dan memasukkan manik-manik ke botol.

\section{b. Sensoris}

Kegiatan yang diberikan untuk membantu mengembangkan sensorik pada anak berkebutuhan khusus yaitu : meniup kapas, membedakan suhu, mendengarkan bunyi-bunyian, melatih 
pengecapan, melatih indra penciuman, melatih indra penglihatan.

c. Kognitif

Kegiatan yang diberikan untuk membantu mengembankan kognitiff pada anak gangguan fisik yaitu : melukis, bermain puzzle, melihat gambar, dan bermain musik.

d. Intrapersonal

Kegiatan yang diberikan untuk membantu mengembangkan intrapersonal pada anak gangguan fisik yaitu : mendengarkan cerita, bernyanyi, bermain drama.

e. Interpersonal

Kegiatan yang diberikan untuk membantu mengembangkan interpersonal pada anak gangguan fisik antara lain: senam irama dan berbelanja.

\section{f. Perawatan diri}

Kegiatan yang diberikan untuk membantu mengembangkan aspek perawatan diri pada nak gangguan fisik yaitu : makan, memakai baju dan minum.

\section{g. Produktifitas}

Kegiatan yang diberikan untuk membantu mengembangkan aspek produktifitas pada anak gangguan fisik antara lain: membuat asbak, berkebun, dan rekreasi.

\section{Terapi Okupasi Untuk Anak Autistik}

Problem dan penyelesaian yang dialami oleh anak autistik yaitu:

a. Motorik

Kegiatan yang diberikan untuk membantu mengembangkan motorik pada anak autistik yaitu: bermain bola, mengayuh sepeda statis.

b. Sensorik

Kegiatan yang diberikan untuk membantu mengembangkan aspek sensorik pada anak autistik yaitu: berayun-ayun, berjalan mengikuti garis tengah lurus, berguling dibalik selimut, dan bermain scooter board.

c. Kognitif

Kegiatan yang diberikan untuk membantu mengambangkan aspek kognitif pada anak autistik yaitu: melihat-lihat gambar mobil, dan memainkan plastisin.

d. Intrapersonal

Kegiatan yang diberikan untuk membantu mengembangkan aspek intrapersonal pada anak autistik yaitu: bermain form board dan melukis.

e. Interpersonal

Kegiatan yang diberikan untuk membantu mengembangkan aspek interpersonal yaitu: berolahraga dan mendengarkan musik. 
f. Perawatan Diri

Kegiatan yang diberikan untuk membantu mengembangkan aspek perawatan diri yaitu: membersihkan tempat tidur dan menyisir rambut.

g. Produktifitas

Kegiatan yang diberikan untuk membantu mengembangkan aspek produktifitas yaitu: bermain kelereng, menyapu lantai, mempersiapkan makan, dan mencuci.

h. Leisure (Pengisian Waktu Luang)

Kegiatan yang diberikan untuk membantu mengembangkan aspek leisure yaitu: membuat keset, memelihara burung dan ayam.

\section{Terapi Okupasi Untuk Anak Hiperaktif}

Problem dan penyelesaian yang dialami oleh anak hiperaktif yaitu:

a. Motorik

Kegiatan yang diberikan untuk membantu mengembangkan aspek motorik yaitu: Menangkap/melempar bola dan lari haral lintang.

b. Sensorik

Kegiatan yang diberikan untuk membantu mengembangkan aspek sensorik yaitu: berjalan mengikuti garis berkelok dan meniru tulisan.

c. Kognitif

Kegiatan yang diberikan untuk membantu mengembangkan aspek kognitif yaitu: bermain tebak - tebakan dan mewarnai.

d. Intrapersonal

Kegiatan yang diberikan untuk membantu mengembangkan aspek intrapersonal yaitu: membersihkan halaman dan bermain ular-ularan.

e. Interpersonal

Kegiatan yang diberikan untuk membantu mengembangkan aspek interpersonal yaitu: membersihkan lingkungan sekolah.

f. Perawatan Diri

Kegiatan yang diberikan untuk membantu mengembangkan aspek perawatn diri yaitu: penggunaan waktu luang dirumah dan bermain halma.

g. Produktifitas

Kegiatan yang diberikan untuk membantu mengembangkan aspek produktifitas yaitu: merangkai bunga dan bermainan berkompetisi.

h. Leisure (Pengisian Waktu Luang)

Kegiatan yang diberikan untuk membantu mengembangkan aspek leisure yaitu: rekreasi dan bermain alat musik.

\section{Daftar Pustaka}

Neely. Margery A.,1982, Counseling and Guidance Practices with Special Education Student, Illinois: The Dorsey Press. 
Sujarwanto, 2005, Terapi Okupasi untuk

Anak Berkebutuan Khusus,

Departemen Pendidikan Nasional Jakarta.

Thomson. L. Charles, Rudolph. Linda. B, Henderson. Donna. A., 2004, Counseling Children Sixth Edition. USA. Brooks/Cole.

Undang-Undang No. 20 Tahun 2003 tentang Sistem Pendidikan Nasional, Depdiknas: Jakarta.

http://qtc-

sby.blogspot.com/2010/01/trainingpenanganan-anakberkebutuhan.html.

http://www.scribd.com/doc/37784461/Bim bingan-Konseling-AnakBerkebutuhan-Khusus.

http://yayasandanterigmalia.blogspot.com 